\title{
POLITICAL LINKAGE AND PUBLIC POLICY: ATTITUDINAL CONGRUENCE BETWEEN GITIZENS AND OFFICIALS
}

\author{
David R. Morgan \\ University of Oklahoma
}

$\mathrm{T}$

IHE NATURE of representation in a democratic political system has long interested political scientists. Without consciously rejecting the Burkean notion of a representative as trustee, recent democratic theorists have increasingly accepted a model of electoral accountability which holds that politicians are made responsive to their constituents by fear of the ballot box. ${ }^{1}$ However, recent research on the urban political process in the San Francisco Bay area suggests that the electoral accountability model hardly operates at the local level. ${ }^{2}$ Instead, many city council members operate on the basis of their own self-defined images of the community's needs with almost open disdain for the will of the majority and with little concern for voter retaliation. Such a situation has serious implications indeed for representative theory as applied to the local polity. The Bay area research, however, offers no evidence that this norm of volunteerism, as it has been called, results in community policies that are out of harmony with local desires and needs. The research reported here attempts to deal with this question and suggests that in one area, at least, nonprofessional local governing bodies may be adhering rather closely to the policy views of the larger community. In effect, an attempt will be made to test a belief-sharing model of political linkage which in certain situations may replace the electoral-accountability model propounded by many contemporary democratic theorists. ${ }^{3}$

\section{The Political Process in Small Communities}

Research on community politics, especially among smaller nonpartisan cities, has frequently highlighted the amateur nature of many local governing bodies. The dearth of prior political experiences on the part of councilmen, the high rate of voluntary turnover among incumbents, selection to office by cooptation or appoint-

Note: I wish to thank Professor Samuel A. Kirkpatrick and Professor F. Ted Hebert of the Department of Political Science, University of Oklahoma, for their help with an earlier draft of this manuscript. Bill Lyons also assisted with several of the required calculations. An earlier version of this paper was presented at the annual meeting of the Southwest Social Science Association, San Antonio, Texas, March 1972.

${ }^{1}$ See the discussion and citations in Kenneth Prewitt, The Recruitment of Political Leaders: A Study of Citizen-Politicians (Indianapolis: Bobbs-Merrill, 1970), pp. 192-96.

2 In addition to several important articles cited later, the City Council Research Project which studied 87 cities in the San Francisco area during 1966 and 1967 resulted in a series of books under the editorship of Heinz Eulau and Kenneth Prewitt. They include the following: Prewitt, op. cit.; Robert Eyestone, The Threads of Policy Leadership (Indianapolis: Bobbs-Merrill, 1970); and Ronald O. Loveridge, City Managers in Legislative Politics (Indianapolis: Bobbs-Merrilil, 1971), with nine future volumes scheduled.

"For a discussion of various political linkage models see Norman Luttbeg, "Political Linkage in a Large Society," in Luttbeg, ed., Public Opinion and Public Policy (Homewood: Dorsey Press, 1968), pp. 1-9. Also see Edward N. Muller, "The Representation of Citizens by Political Authorities: Consequences for Regime Support," American Political Science Review, 64 (December 1970), 1149-66. 
ment, fewer contested elections, and the lower turnout rates for local elections have all been singled out as evidence of the nonprofessional character of most small community governments. ${ }^{4}$ Attitudinal studies also confirm this nonprofessional political orientation among local officials. In a study of 37 city councils in the St. Louis area, Downes noted that many of the councilmen perceived themselves as being somehow "above politics." Therefore they worried very little about being reelected; in fact, it was observed that, "many would just as soon not be reelected...." 5 Black's data from the Bay area corroborate these findings as over half the council respondents defined their position in strictly "nonpolitical" terms. ${ }^{6}$

Despite the abundance of evidence that many city councils, especially in smaller communities, are manned by part-time amateurs with little appreciation for the art of politics, little effort had been made to relate these findings to the broader concerns of democratic theory. The Bay area research has now accomplished that task most admirably and with profoundly disturbing effect. Eulau, Prewitt, and Black ${ }^{7}$ indicate that the drive for reelection among Bay area local officials, so crucial for the operation of representative government, is largely absent. Instead, a strong norm of "volunteerism" characterizes the political orientations of these officials suggesting that council service is considered primarily as a citizen duty, much the same as service in the Chamber of Commerce, PTA, or other local civic groups. Where the norm of volunteerism is particularly prevalent, according to Prewitt, councils are "(a) more likely to vote against what they see as majority opinion, (b) less likely to feel under pressure from the public, (c) less likely to consider the upcoming election when choosing among policy alternatives, (d) less likely to facilitate group access to the council, and (g) less likely to perform services for constituents." s

When a council is relatively oblivious to external influences and unconcerned with reelection, its members are most likely to entertain a self-defined image of what community needs are. Prewitt and Eulau determined that 44 percent of the Bay area councils tended to view community needs in terms of their own self-perceptions. ${ }^{2}$ This frame of reference which largely ignores outside pressures is obviously at odds with the contemporary model of electoral accountability. In Schlesinger's

${ }^{4}$ See Eugene C. Lee, The Politics of Nonpartisanship (Berkeley: University of California Press, 1960); Oliver P. Williams and Charles R. Adrian, Four Cities (Philadelphia: University of Pennsylvania Press, 1963); Paul A. Smith, "The Games of Community Politics," Midwest Journal of Political Science, 9 (February 1965), 37-60; L. W. O'Rourke, Voting Behavior in Forty-five Cities of Los Angeles County (Los Angeles: University of California, Bureau of Government Research, 1953); and R. L. Stauber and Mary Kline, "Profile of City Commissioners in Kansas," Your Government (Lawrence: University of Kansas, Governmental Research Center, April 1965).

"Bryan T. Downes, "Municipal Social Rank and the Characteristics of Local Political Leaders," Midwest Journal of Political Science, 12 (November 1968), 514-37.

"Gordon S. Black, "A Theory of Professionalization in Politics," American Political Science Review, 64 (September 1970), 865-78.

'Kenneth Prewitt and Heinz Eulau, "Political Matrix and Political Representation: Prolegomenon to a New Departure from an Old Problem," American Political Science Review, 63 (June 1969), 427-41; Prewitt, "Political Ambitions, Volunteerism, and Electoral Accountability," American Political Science Review, 64 (March 1970), 5-17; Black, op. cit.

${ }^{8}$ Prewitt, "Political Ambitions," p. 11.

- Prewitt and Eulau, op. cit., p. 430. 
words: "No more irresponsible government is imaginable than one of high-minded men unconcerned for their political futures." 10

The Bay area research does not suggest that councils which define community needs in their own self-images lack the support of the community. To the contrary, councils from small relatively homogeneous cities were not only the most likely to selfdefine community needs but also were the most likely to perceive relatively high community support ${ }^{11}$ permitting the governing body freely to pursue community interests as it saw fit. At no point, however, do the Bay area reports discuss any relationship between the council's policy images and those of the citizens they represent. ${ }^{12}$ Prewitt and Eulau admit that the councils which are attuned to their own definition of community preferences, in fact, may be in accord with public wishes. This relationship is never tested, however. The research reported below will attempt to shed additional light on this question of attitudinal congruence between council members and those they represent.

First, we might note that there are several reasons why city councils, especially those from small homogeneous communities, nonprofessional as they are, might function so as to reflect the will of the majority. Robert Wood has recognized that the small-town, grass-roots atmosphere of suburbia may result in a nonpolitical governing process quite satisfactory to the majority. In such places, he argues, we may even find popular control unchecked by a notion of minority rights. The tyranny of the small-town majority, according to Wood, may stifle debate and discussion resulting in a uniformity of attitude and outlook, "a certainty of the rightness of the majority which amounts to compulsion." ${ }^{13}$ Under such conditions, elections might seem almost superfluous as a way of guiding local policy decisions. Other means may exist for making relatively certain that local public policy is congruent with majority views. Research has revealed, for example, that local officials ordinarily reflect the general social and economic background of those they represent. ${ }^{14}$ This alone tells us nothing about the coincidence of attitudes between leaders and nonleaders, but this same research suggests that people who share residence in the same suburban sociopolitical unit may indeed share certain uniform value connotations. As Williams and associates observe, "identification with a particular community is achieved by adopting the dominant values of the community as one's own... homogeneous attitudes are furnished social support which help reassure one of the wisdom of his views." 15

${ }^{10}$ Joseph A. Schlesinger, Ambition and Politics (Chicago: Rand McNally, 1966), p. 2.

"Community support was based strictly on the councilmen's own perception of the degree of local support and not on any data actually collected on community attitudes. Prewitt and Eulau, op. cit., p. 434.

${ }^{13}$ Another Bay area report discusses policy orientations of council members but does not compare them with citizen attitudes. See Heinz Eulau and Robert Eyestone, "Policy Maps of City Councils and Policy Outcomes: A Development Analysis," American Political Science Revieze, 62 (March 1968), 124-43.

${ }^{13}$ Robert C. Wood, Suburbia: Its People and Their Politics (Boston: Houghton Mifflin, 1958), p. 273.

${ }^{14}$ See Henry J. Schmandt, "The City and the Ring," American Behavioral Scientist, 4 (November 1960), 17-19; Charles Gilbert, Governing the Suburbs (Bloomington: Indiana University Press, 1967), pp. 260-61; and Downes, op. cit.

${ }^{15}$ Oliver Williams et al., Suburban Differences and Metropolitan Policies (Philadelphia: University of Pennsylvania Press, 1965), p. 236. 
Without further discussion of the various means at hand to insure attitudinal congruence between elected councils and those they represent, we might turn to the need for empirical verification of this phenomenon. Can an amateur, apolitical local governing body largely oblivious to the electoral norms required by the theory of representation accurately reflect the attitudes and policy preference of the larger citizenry it represents?

\section{Community Leader-Follower Studies}

Before taking up the data at hand, it might be appropriate to consider briefly previous research concerning the linkage between leader and follower attitudes, although only a limited number of studies have been undertaken at the community level making efforts at generalization somewhat tenuous. Data from the Philadelphia area indicated that municipal policies of sixteen suburbs were generally consistent with the attitudes and opinions of community residents, ${ }^{16}$ although the study of two Oregon communities found that leaders tended to express greater approval than did the public of certain current local public programs and proposed innovations. ${ }^{17}$ Other findings suggest that the capacity of local leaders to predict follower attitudes was issue-related and that leaders were more dissatisfied than were constituents with certain public programs and more anxious to bring about reform. ${ }^{18}$ Studies of attitudes toward metropolitan political integration indicated that public officials were more inclined to extreme views than were residents, although suburban officials were closer to the attitudes of their constituents than were central city officials. ${ }^{19}$ The opposite situation prevailed when attitudes of school officials were compared with those of their constituents on questions of school district reorganization. Central city officials displayed a real capacity to evaluate correctly follower attitudes, while suburban school officials consistently overstated the amount of opposition to reorganization existing in the suburbs. The size of the gap between officials and residents, however, declined in the smaller suburbs. ${ }^{20}$

Based on this limited local leader-follower literature and the argument offered above that officials and their constituents might be expected to share policy preferences when considerable community homogeneity exists, four hypotheses are offered concerning the circumstances under which suburban city councils might be expected fairly accurately to mirror resident wishes.

1. Suburban residents and council members will manifest attitudinal agreement on the basic policy orientations for local government;

${ }^{16}$ Ibid., p. 221.

${ }^{17}$ Norman R. Luttbeg, "Patterns of Leadership Policy Preferences: A Study of Some Assumptions in Community Research," in Luttbeg, op. cit., pp. 355-64. Also see Luttbeg, "The Structure of Beliefs Among Leaders and the Public," Public Opinion Quarterly, 32 (Fall 1968), 398-409.

${ }^{18}$ Roberta S. Sigel and H. Paul Friesema, "Urban Community Leaders' Knowledge of Public Opinion," Western Political Quarterly, 18 (December 1965), 881-95.

${ }^{19}$ Amos H. Hawley and Basil G. Zimmer, The Metropolitan Community (Beverly Hills, California: Sage, 1970).

${ }^{20}$ Basil G. Zimmer and Amos H. Hawley, "Opinions on School District Reorganization," Social Science Quarterly, 48 (December 1967), 311-324. 
2. Suburban citizens and officials will tend to evaluate urban services in a generally similar way with officials offering slightly more generous appraisals of service levels;

3. Suburban citizens and officials will tend to share a similar outlook concerning certain protective features of suburban life although officials will exhibit slightly more extreme views;

4. Similar attitudes toward suburban taxes will be expressed by citizens and officials except that officials, by virtue of their position, will tend to express more favorable views.

In general, we will expect the attitudes of local officials to reflect reasonably the views of those they represent with one fairly consistent difference. On most matters which directly relate to the distinctive advantages of suburban life, we will anticipate that officeholders will represent a more extreme position than their constituents. In addition, the relationships hypothesized above should prevail whether or not councilmen are adhering to norms of volunteerism, although in the setting for this study, considerable evidence suggests that the officials are overwhelmingly amateurs. For example, when these suburban leaders are divided on the basis of community social rank, ${ }^{21}$ the following responses were reported regarding their political background and motivation for officeholding:

4 years of council service or less

held or ran for previous elected office

got interested through friends or just wanted to serve

appointed or asked to run by another council member
Upper social rank

$71 \%$

14

71

43
Lower social Rank

$41 \%$

18

65

35

Only three councilmen mentioned issues as being the motivating force to run for office, and only one person mentioned being contacted by any political party official or elected partisan officeholder.

The data for the study were gathered in 1967 from a systematic sample of residents (taken from city directories and utility lists) from five suburban communities within the Oklahoma Gity metropolitan area, and mail questionnaire responses from council members from the same five suburbs. The five cities (with 1967 population estimates) are as follows: Del City $(28,325)$; Bethany $(20,001)$; The Village $(15,395)$; Warr Acres $(9,669)$; and Nichols Hills $(4,897)$. Using a standard employment-residence ratio, ${ }^{22}$ all five suburbs are "dormitory" types. The municipalities have similar governmental structures: four of the five have city managers; all employ nonpartisan ballots; and only one elects its city council on a strictly ward basis. The cities were selected to represent all levels of community social rank found

\footnotetext{
${ }^{21}$ The social rank typology as developed by Eshref Shevky and Wendell Bell in Social Area Analysis (Stanford: Stanford University Press, 1955), pp. 54-55, includes only education and occupation.

${ }^{22}$ Leo F. Schnore, "The Functions of Metropolitan Suburbs," American Journal of Sociology, 61 (March 1956), 453-58.
} 
among the ten suburbs of over 2,500 population within the SMSA. Table 1 reports variations among the five suburbs with respect to educational, occupational and income differences based on 1960 census data, although the standardized score used to compute social rank is based only upon education and occupational variations.

TABLE 1

Educational, Occupational, and Income Levels for Five Oklahoma City Area Suburbs, 1960

\begin{tabular}{|c|c|c|c|c|}
\hline & $\begin{array}{l}\text { Median Family } \\
\text { Income }\end{array}$ & $\begin{array}{l}\text { Completed High } \\
\text { School or More }\end{array}$ & $\begin{array}{c}\text { White Collar } \\
\text { Occupation }\end{array}$ & $\begin{array}{c}\text { Standardized Score* } \\
\text { (Education } \\
\text { and Occupation) }\end{array}$ \\
\hline 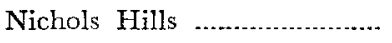 & $\$ 10,000+$ & $86.3 \%$ & $86.1 \%$ & $100.0 \%$ \\
\hline 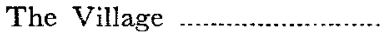 & 7,937 & 83.4 & 77.7 & 85.4 \\
\hline 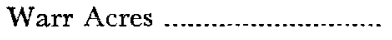 & 6,907 & 68.5 & 57.7 & 39.0 \\
\hline Bethany & 5,522 & 51.4 & 46.3 & 0.9 \\
\hline 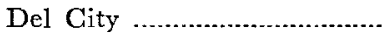 & 5,905 & 50.8 & 46.9 & 0.8 \\
\hline
\end{tabular}

* Since the raw percentages are not additive, they were standardized on the range 0-100 using the formula: $S=X(r-0)$, where $S=$ standard score, $X=100 /$ range of the measure, $x=$ value for particular community, and $o=$ lower limit of the measure. Education and occupation scores were then averaged to get the standardized score. Although Warr Acres is clearly in the middle, a cutting point of 50.0 was established to distinguish high and low social rank, which placed that suburb in the lower social ranked group. This appears satisfactory for intuitive reasons as well since this city is physically adjacent to Bethany and the two are often considered as a pair.

Both groups of respondents were asked questions which dealt with many of the more important and controversial issues of suburban life. The two broad areas queried included (1) evaluation of local government services and taxes, and (2) those qualities of suburban life which provide protection from some of the allegedly unpleasant aspects of central city living.

\section{Policy Agreement Between Crtizens and Officials}

While urban policies have been the focus of considerable recent attention, ${ }^{\mathbf{2 3}}$ most research has actually dealt with a limited number of policy indicators, in particular tax and revenue measures. As useful as this may be for research purposes, the average citizen does not evaluate the performance of his local government in such abstract terms. His support will likely be closely related to his satisfaction or dissatisfaction with service outputs. The service producing aspect of the municipality should be especially salient for the suburbanite since his local polity is far less involved with the other basic function of city government, the regulation of conflict. ${ }^{24}$ In the study at hand, for example, when asked for reasons why they liked suburban living, good city services was mentioned by 61.4 percent of the citizen sample (good schools ranked first at 63.7 percent).

Eulau and Eyestone have demonstrated that the policy orientations of urban decision-makers contribute to the shape of local policy outputs. ${ }^{25}$ For this reason, policy-makers' perceptions of city problems and their evaluation of urban services

\footnotetext{
${ }^{28}$ For a good summary of much of this research see Brett W. Hawkins, Politics and Urban Policies (Indianapolis: Bobbs-Merrill, 1971).

34 See the Introduction in Edward C. Banfield and James Q. Wilson, City Politics (Cambridge: Harvard-MIT Press, 1963), for a good discussion of the basic purposes of municipal government.

${ }^{3}$ Eulau and Eyestone, op. cit.
} 
are of considerable consequence for the way in which communities adapt to the pressures of their local environment. ${ }^{26}$ Moreover, the degree of support forthcoming for the local political authorities may be a result, in large measure, of their capacity to assess correctly the community's desire for adequate urban services. It would seem appropriate, then, to begin our analysis of attitudinal congruence between citizens and authorities with an examination of service evaluations.

Perhaps the most meaningful way of exploring attitudinal linkages between officials and citizens would be to compare the views of residents from a given cormmunity directly with those who represent them (their own councilmen, for example). That approach is difficult in a study such as this because of the small numbers involved since most suburban councils are quite limited in size. As a partial solution to this dilemma, the five suburbs were divided into two relatively homogeneous groups based on community social rank. A somewhat natural split existed between the two upper status suburbs and the other three communities which form the lower social rank category. The data which follow will make comparisons between leaders and followers from the upper social rank communities and the same two groups from the lower ranked suburbs. To further compare officials' and citizens' attitudes on some issues, a ratio of support was calculated for each group. ${ }^{27}$ This index was developed by assigning a weight of 1.0 to each "yes" (or "favor") response and a 0 to each "no" (or "oppose") answer. Where responses of the "same" or some additional intermediate category were used, they were weighted as .5. The support ratio for any group is in effect a mean score with a possible range of 0 to 1.0 in which support for a particular issue increases as the support ratio approaches unity. Thus it becomes possible to observe the degree to which the paired comparisons (e.g., upper ranked leaders and followers) are alike other than by merely comparing percentage differences. For purposes of assessing attitudinal congruence between suburban officials and residents, we will assume that differences in support ratio scores approximate the following overall levels of agreement: 0 to .25 - strong agreement; .26 to .50 - moderate agreement; .51 to .75 -- moderate disagreement; .76 to 1.00 - strong disagreement.

Both council members and the public were asked to evaluate eight basic urban services using the categories "very good" (rated 1), "good," "fair," and "poor" (rated 4). Table 2 reveals considerable similarity in the average service ratings when citizens and officials are compared by community social rank. As anticipated, councilmen representing upper rank communities provide the most generous evaluations of local services while citizens from lower ranked suburbs are the least charitable. Nevertheless, considerable agreement exists between residents and councilmen from both kinds of communities with the highest level of congruence occurring between leaders and followers for the upper status suburbs. Council members and

\footnotetext{
${ }^{28}$ For another perspective on how attitudes of local officials toward services may affect policy preferences see Samuel A. Kirkpatrick and David R. Morgan, "Policy Support and Orientations Toward Metropolitan Political Integration Among U rban Officials," Social Science Quarterly, 52 (December 1971), 656-71.

${ }^{27}$ The support ratio follows that in Herbert McCloskey, Paul Hoffman, and Rosemary O'Hara, "Issue Conflict and Consensus Among Party Leaders and Followers," American Political Science Review, 54 (June 1960), 406-27.
} 
their constituents not only rate local services quite high but tend to rank them in substantially the same order as reflected by the high rank order correlation coefficients of .94 and .76 (Kendall's tau corrected for ties).

TABLE 2

Suburban Citizens' and Officials' Ratings for Urban Services BY Community Sogial Rank*

\begin{tabular}{|c|c|c|c|c|}
\hline \multirow[b]{2}{*}{ Service } & \multicolumn{2}{|c|}{$\begin{array}{c}\text { Citizens } \\
\text { Community Sogial. Rank } \\
\end{array}$} & \multicolumn{2}{|c|}{$\begin{array}{c}\text { Ofricials } \\
\text { Community Social Rank }\end{array}$} \\
\hline & Upper $(n=60)$ & Lower $(n=163)$ & $\overline{U_{p p e r}(n=7)}$ & Lower $(n=17)$ \\
\hline Police & 1.24 & 1.55 & 1.00 & 1.29 \\
\hline Fire & 1.29 & 1.59 & 1.00 & 1.24 \\
\hline Schools ........ & 1.55 & 1.46 & $1.40 \dagger$ & 1.35 \\
\hline Garbage & 1.72 & 1.94 & 1.40 & 1.35 \\
\hline Planning & 1.94 & 2.01 & 1.57 & 2.06 \\
\hline Traffic & 2.02 & 2.23 & 1.71 & 2.12 \\
\hline 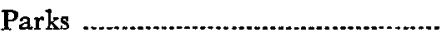 & 1.98 & 2.33 & 1.71 & 2.53 \\
\hline Street & 2.71 & 2.71 & 2.14 & 2.71 \\
\hline Mean Service Rating & 1.81 & 1.98 & 1.49 & 1.83 \\
\hline \multicolumn{2}{|c|}{$\tau=.94$ (upper rank communities) } & \multicolumn{3}{|c|}{$\tau=.76$ (lower rank communities) } \\
\hline
\end{tabular}

* Services were rated as "very good" 1; "good" 2; "fair" 3; and "poor" 4 .

$\dagger$ Four of seven officials gave a "not applicable" response since their suburbs are part of the larger central city school district.

In addition to rating local services, councilmen and residents were asked to express their views concerning basic policy directions for their communities. The questions were framed around the threefold urban policy typology developed by Williams and Adrian in Four Cities. ${ }^{28}$ Respondents were asked whether it was "very important," "important," or "not important" that the city (1) promote economic growth; (2) provide amenities; and (3) maintain (only) traditional services. Respondents were also queried concerning the importance of preserving the social character of the suburbs since this emerged as an important suburban policy goal in the later study of the Philadelphia area by Williams et al. ${ }^{29}$

Table 3 presents the comparisons between suburban officials and citizens by community social rank for these local government policy orientations. Where differences appear it is often on those measures where upper ranked council members were more adamant concerning the special features of their exclusive domains. For example, none of the officials from upper status suburbs think that getting more business and industry for the community is "very important." In fact, over 85 percent indicate this is "not too important" compared to a figure of only 40.0 percent among upper rank residents. Closer agreement on this basic value is found among citizens and officials from the three lower ranked communities, although again there is a good bit more support for economic growth among followers than leaders (a support ratio of .78 to .59 ). It is somewhat surprising that so much favorable sentiment for suburban economic development appears among residents of these dormitory suburbs. Two factors may help to account for this. First, the metropolitan press constantly urges greater growth and development for the area. Even recent

\footnotetext{
${ }^{28}$ See Part III.

Williams, op. cit., Chap. 8.
} 
TABLE 3

Suburban Cittizens' and Officials' Attitudes Toward Proper Poligy Orientatton for Local Government by Community Social Rank

\begin{tabular}{|c|c|c|c|c|}
\hline & $\begin{array}{r}\mathrm{Cr} r \\
\text { Commurit }\end{array}$ & IZENS & $\begin{array}{r}\text { OFF } \\
\text { CoMMUNIrY }\end{array}$ & SOGIAL RANK \\
\hline & Upper $(n=60)$ & Lower $(n=I \overline{6})$ & $\operatorname{Upper}(n=7)$ & Lower $(n=17)$ \\
\hline Improve Public Services & & & & \\
\hline$\%$ favoring: very important & 35.0 & 40.4 & 71.4 & 58.8 \\
\hline important & 46.7 & 43.6 & 0 & 41.2 \\
\hline not too important $\ldots . .$. & 18.3 & 16.0 & 28.6 & 0 \\
\hline support ratio & .52 & .69 & .71 & .79 \\
\hline Get More Business and Industry & & & & \\
\hline$\%$ favoring: very important & 31.7 & 60.1 & $\mathbf{0}$ & 29.4 \\
\hline important & 28.3 & 35.6 & 14.3 & 58.8 \\
\hline not too important & 40.0 & 4.3 & 85.7 & 11.8 \\
\hline 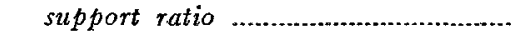 & .49 & .78 & .10 & .59 \\
\hline Keep Tax Rate Low & & & & \\
\hline$\%$ favoring: very important & 40.0 & 47.9 & 0 & 17.6 \\
\hline important & 50.0 & 44.1 & 57.1 & 52.9 \\
\hline not too important ....... & 10.0 & 8.0 & 42.9 & 29.5 \\
\hline support ratio & .65 & .70 & .29 & .44 \\
\hline Keep Out Undesirables & & & & \\
\hline$\%$ favoring: very important & 51.7 & 41.7 & 28.6 & 41.2 \\
\hline important & 23.3 & 36.2 & 28.6 & 35.3 \\
\hline not too important & 25.0 & 14.1 & 42.8 & 23.5 \\
\hline support ratio & .63 & .60 & .43 & .59 \\
\hline Maintain Peaceful Community & & & & \\
\hline$\%$ favoring: very important & 61.7 & 60.1 & 57.1 & 47.1 \\
\hline important & 28.3 & 32.5 & 42.9 & 35.3 \\
\hline not too important ....... & 10.0 & 7.4 & 0 & 17.6 \\
\hline support ratio & .76 & .76 & .79 & .65 \\
\hline
\end{tabular}

campaigns for governor have stressed the importance of getting more jobs for the state. Second, none of these communities has any heavy industry, nor for that matter does the central city have many examples of the kind of industry which produces undesirable side effects. Thus the general citizenry of the metropolitan area has been subjected to a continuous propaganda effort in behalf of growth and economic expansion with few examples of any adverse results which might come with extensive industrial development.

Rather close agreement exists between officeholder and citizen from both community rank levels on the matter of improving public services. Somewhat surprisingly the greatest support for improving local services turns up among officeholders and their constituents from lower social ranked suburbs. Not nearly as much similarity, however, is found on the question of keeping tax rates low. As anticipated, the general citizenry is more tax conscious than its elected representatives. On this matter much greater consensus exists among residents irrespective of social rank than between citizens and officials from either upper or lower status communities. The support ratios indicate that lower ranked suburbanites are the most interested in keeping taxes down while upper ranked officials are least concerned. 
Stronger linkages exist between leaders and followers on questions concerning the quality of life in suburbia than on any of the three policy orientations shown in Table 3. There is almost exact agreement between lower ranked officials and citizens on keeping "undesirables" out of the community. On the other hand, while upper ranked residents gave this issue the greatest support, their elected representatives are the least concerned about "keeping out undesirables." Maintaining a peaceful community is a high priority item for suburban residents and officeholders regardless of community status. ${ }^{30}$ The greatest consensus on this policy measure is found in the upper ranked communities although the attitudinal convergence is high for citizens and officials from the lower status communities as well. In all, closer policy congruence exists on those matters which seem related to protecting the suburban life style as indicated by the following average support ratios for the latter mentioned two policies:

\begin{tabular}{cccc} 
upper rank officials & .61 & lower rank officials & .62 \\
upper rank citizens & .69 & lower rank citizens & .68 \\
\cline { 2 - 6 } difference & .08 & difference & .06
\end{tabular}

The average support ratios for the other three policy areas pertaining to acquiring business, improving services, and keeping taxes down are as follows:

\begin{tabular}{cccc} 
upper rank officials & .37 & lower rank officials & .61 \\
upper rank citizens & .55 & lower rank citizens & .72 \\
\cline { 2 - 5 } difference & .18 & difference &
\end{tabular}

Two comments seem appropriate concerning the above findings. First, the closest attitudinal ties between residents and their officials on basic policy directions are found in the lower ranked suburbs. This was not altogether expected since it was believed that the upper status community leaders would be the most attuned to the views of their constituencies. This expectation was derived largely from the research indicating the greater political involvement and awareness of those with higher levels of education, occupation and income. ${ }^{31}$ Part of the reason why the lower ranked groups evidence a higher level of agreement results from the large difference between upper rank citizens and officials on the importance of bringing new business and industry into the community. As Table 3 reveals, the leaders from the two upper status suburbs were considerably less willing than their constituents to see greater economic expansion within their communities. It may be that in a state which has constantly sought industrial expansion, the larger public is less discriminating about the potential problems associated with economic growth than is the leadership element. And, second, of the ten pairs of comparisons, only three differences in support ratio were not within the .25 level, mentioned earlier as indicating strong agreement (the exceptions were leaders and followers from both types of suburb on the tax question and upper rank citizens and officials on the issue of economic growth).

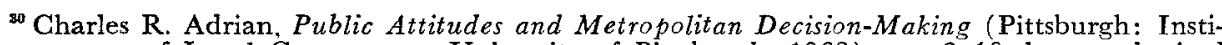
tute of Local Government. University of Pittsburgh, 1962), pp. 8-10, has emphasized the importance to most middle-class suburbanites of having a local government with a "minimal anxiety-producing potential."

${ }^{\text {"S }}$ See Lester W. Milbrath, Political Participation (Chicago: Rand McNally, 1965), Chap. 3.
} 


\section{Attitudinal Congruence on Additional Suburban Issues}

Some have argued that suburban dwellers cling to their separate legal independence not so much from a deep feeling of attachment and dedication to their miniature republic, but rather because they fear change may bring higher taxes, invasion by Negroes and other core city "undesirables," downgrading of the local public school system or loss of certain privileges peculiar to the suburban enclave. ${ }^{32}$ Several questions were included in the survey which permit a comparison of responses by suburbanites and their elected council members to such issues as a further way of analyzing leader-follower political linkages. In the area of local taxes we might anticipate a good deal of similarity in outlook between citizens and officials except that, as noted above, council members are not apt to be as sensitive to the desire for low taxes as are residents. This is understandable in light of the necessity for council members to meet expanding service demands with rather limited local budgets. Table 4 generally confirms our expectations when the two groups are

TABLE 4

Suburban Crtizens' and Officials' Attttudes Toward Level of Local Taxes by Community Social Rank

\begin{tabular}{|c|c|c|c|c|}
\hline \multirow{2}{*}{$\begin{array}{l}\text { Perceived Level of } \\
\text { Local Taxation }\end{array}$} & \multicolumn{2}{|c|}{$\begin{array}{c}\text { CitTZENS } \\
\text { CoMMUNITY SOCIAL RANK }\end{array}$} & \multicolumn{2}{|c|}{$\begin{array}{c}\text { OpFICIALS } \\
\text { CoMMUNITY SOCIAL RANK }\end{array}$} \\
\hline & Upper $(n=60)$ & Lower $(n=163)$ & Upper $(n=7)$ & Lower $(n=17)$ \\
\hline Too high. & $10.0 \%$ & $33.1 \%$ & $14.3 \%$ & $11.8 \%$ \\
\hline About right & 81.7 & 57.0 & 71.4 & 47.0 \\
\hline Too low & 1.7 & 4.3 & 14.3 & 41.2 \\
\hline Don't know & 6.7 & 5.6 & 0.0 & 0.0 \\
\hline & $\overline{100.0 \%}$ & $\overline{100.0 \%}$ & $\overline{100.0 \%}$ & $\overline{100.0 \%}$ \\
\hline support ratio & .54 & .68 & .50 & .35 \\
\hline
\end{tabular}

asked about the local tax burden. The linkage is quite strong for upper ranked suburbanites and their representatives while somewhat less congruence is reflected for citizens and officials from the other communities. The attitudinal correspondence on this issue for the upper ranked communities is surprisingly close while the officials from the lower ranked suburbs deviate from their constituents more in the expected direction (with councilmen much more likely to think taxes are too low). In Table 5 councilmen and residents are compared on a question concerning whether they perceive suburban taxes to be lower than those in the central city. A high degree of similarity in outlook exists for officials and citizens in both types of communities. Upper rank officeholders are especially sure that their suburb has a tax advantage over the central city while lower rank citizens are the least certain. ${ }^{33}$

${ }^{32}$ For example, see John C. Bollens and Henry J. Schmandt, The Metropolis: Its People, Politics, and Economic Life (New York: Harper and Row, 1965), p. 221.

${ }^{33}$ There is no reason to believe that wide property tax differentials exist among the suburbs or between suburbs and central city since all the communities in the study are part of Oklahoma County and subject to assessment by the same county assessor (assessment is not done by municipalities in Oklahoma). However, the suburbs frequently do have somewhat lower bonded indebtedness, and thus suburbanites may actually pay slightly lower taxes than central city dwellers. 
TABLE 5

Suburban Citizens' and Officials' Attitudes on Local Tax Differential Between Suburb and Gentral Gity by Community Social Rank

\begin{tabular}{|c|c|c|c|c|}
\hline \multirow{2}{*}{$\begin{array}{l}\text { Suburban Taxes } \\
\text { Lower }\end{array}$} & \multicolumn{2}{|c|}{$\begin{array}{c}\text { Citrizens } \\
\text { Communtry Social RanK } \\
\end{array}$} & \\
\hline & Upper $(n=60)$ & Lower $(n=163)$ & $\overline{\operatorname{Upper}(n=7)}$ & Lower $(n=17)$ \\
\hline Yes & $75.0 \%$ & $44.2 \%$ & $85.7 \%$ & $76.5 \%$ \\
\hline Same & 10.0 & 14.1 & 14.3 & 17.6 \\
\hline No & 6.7 & 12.9 & 0.0 & 5.9 \\
\hline \multirow[t]{2}{*}{ Don't know } & 8.3 & 28.8 & 0.0 & 0.0 \\
\hline & $100.0 \%$ & $100.0 \%$ & $100.0 \%$ & $100.0 \%$ \\
\hline support ratio ....................................... & .87 & .72 & .93 & .85 \\
\hline
\end{tabular}

Racial integration for the suburbs also appears to be the sort of crucial issue which would permit a good test of attitudinal linkages between suburban officials and citizens since the move to suburbia is often characterized as "white flight." Two matters which should be especially salient for suburbanites have to do with open occupancy and busing Negro children into white schools to promote greater racial balance. Officeholders and residents were queried concerning their views toward a local open housing ordinance for their suburb. ${ }^{34}$ Table 6 reveals very little support for this proposition from any of the groups, although the councilmen and residents of the lower ranked suburbs are the least hostile toward this idea. The support ratios between leaders and followers for this question are exceedingly close as Table 6 reveals.

TABLE 6

Suburban Citizens' and Officials' Attitudes Toward Open Housing Law by Community Soclal Rank

\begin{tabular}{|c|c|c|c|c|}
\hline \multirow{2}{*}{$\begin{array}{l}\text { Attitudes On } \\
\text { Open Housing }\end{array}$} & \multicolumn{2}{|c|}{$\begin{array}{c}\text { CrTizens } \\
\text { CoMmunity SOCIAL RANK }\end{array}$} & \multicolumn{2}{|c|}{$\begin{array}{c}\text { OFFICIALs } \\
\text { CoMMUNITY SOCIAL RANK }\end{array}$} \\
\hline & Upper $(n=60)$ & Lower $(n=163)$ & Upper $(n=7)$ & Lower $(n=17)$ \\
\hline 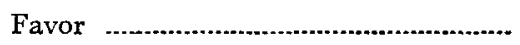 & $16.7 \%$ & $25.8 \%$ & $14.3 \%$ & $23.5 \%$ \\
\hline Oppose & 75.0 & 62.6 & 57.1 & 47.1 \\
\hline \multirow[t]{2}{*}{ Don't know or Refused } & 8.3 & 11.6 & 28.6 & 29.4 \\
\hline & $100.0 \%$ & $100.0 \%$ & $100.0 \%$ & $100.0 \%$ \\
\hline 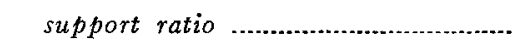 & .18 & .29 & .20 & .33 \\
\hline
\end{tabular}

Overwhelming opposition is manifested by both residents and their local representatives to the idea of busing Negro school children to suburban schools to improve racial balance as Table 7 shows. A modicum of support for this unpopular proposal is found among lower ranked residents, but officials from all five communities unanimously reject the notion. Because a very small degree of approval emerges for the resident sample and none for the office holders, the support ratios for this question are not as close as for the previous one, although the differences are less than .25 .

${ }^{34}$ At the time of this survey none of the five suburbs had an open housing ordinance. 
TABLE 7

Suburban Gitizens' and Officials' Atritudes Toward Busing to Achieve Racial Balance in Schools by Community Social Rank

\begin{tabular}{|c|c|c|c|c|}
\hline \multirow{2}{*}{$\begin{array}{c}\text { Attitude Toward } \\
\text { Busing } \\
\end{array}$} & \multicolumn{2}{|c|}{$\begin{array}{c}\text { CITIZENS } \\
\text { CoMm UNITY SoGial Rank } \\
\end{array}$} & \multicolumn{2}{|c|}{$\begin{array}{c}\text { OfFIGIALS } \\
\text { CoMMUNITY SOCIAL RANK }\end{array}$} \\
\hline & Upper $(n=60)$ & Lower $(n=163)$ & $\overline{U p p e r}(n=7)$ & Lower $(n=17)$ \\
\hline Favor & $10.0 \%$ & $15.3 \%$ & 0 & 0 \\
\hline Oppose & 76.7 & 74.8 & $100 \%$ & $100 \%$ \\
\hline 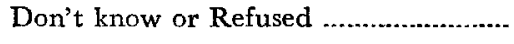 & 13.3 & 10.9 & 0 & 0 \\
\hline & $100.0 \%$ & $100.0 \%$ & $100.0 \%$ & $100.0 \%$ \\
\hline 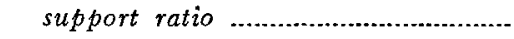 & .11 & .17 & 0 & 0 \\
\hline
\end{tabular}

Two substantive conclusions might be drawn with respect to the questions concerning race. The evidence overwhelmingly supports Adrian's statement that "the balkanized pattern of suburban America is not designed to help solve the national problem of racial and group conflict." ${ }^{35}$ Second, suburbanites (and their officials) are quite reluctant to approve "forced" open housing while, at the same time, finding almost no favor with the idea of busing school children to achieve racial balance in the public schools. Yet these are often the same people who appear before school boards to argue that they don't really oppose school integration but merely busing. Perhaps the inherent contradiction in their attitudes escapes them, or else they must believe they have no responsibility for the broader problem of how some measure of school integration is to be achieved (perhaps it's considered strictly a central city problem).

A final question was included concerning whether respondents think local municipal officials "generally represent the views of most residents" in their city. Table 8 reveals that officials (especially from upper level suburbs) consider themselves as highly representative while their constituents are not quite so convinced. The support ratio difference for the two upper ranked groups slightly exceeds the .25 level of strong agreement while a greater degree of congruence exists for residents and officials in the other suburbs.

TABLE 8

Suburban Citizens' and Officials' Attitudes Concerning Whether Local Officials Represent Gonstituents' Views by Community Social Rank

\begin{tabular}{|c|c|c|c|c|}
\hline \multirow{2}{*}{$\begin{array}{c}\text { Officials Represent } \\
\text { Views }\end{array}$} & \multicolumn{2}{|c|}{$\begin{array}{c}\text { Crtizens } \\
\text { Com Munity Soctal Rank } \\
\end{array}$} & \multicolumn{2}{|c|}{$\begin{array}{c}\text { Ofricials } \\
\text { Community Social RANK }\end{array}$} \\
\hline & Upper $(n=60)$ & Lower $(n=163)$ & Upper $(n=7)$ & Lower $(n=17)$ \\
\hline To a great extent & $53.3 \%$ & $39.3 \%$ & $100.0 \%$ & $70.6 \%$ \\
\hline Only to some extent $\ldots$ & 28.3 & 30.7 & 0 & 29.4 \\
\hline Not very much & 10.0 & 4.3 & 0 & 0 \\
\hline Don't know & 8.4 & 25.7 & 0 & 0 \\
\hline & $\overline{100.0 \%}$ & $100.0 \%$ & $100.0 \%$ & $100.0 \%$ \\
\hline 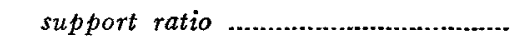 & .74 & .74 & 1.00 & .85 \\
\hline
\end{tabular}

In summary, rather close attitudinal congruence apparently exists in a number of important policy areas between residents and council members from five

\footnotetext{
${ }^{35}$ Charles R. Adrian and Charles Press, Governing Urban America (4th ed.; New York: McGraw-Hill, 1972), p. 50.
} 
Oklahoma City area suburbs. Table 9 summarizes the variations which exist by comparing differences between support ratio scores for citizens and officials from upper and lower ranked suburbs on each of the ten issues which were presented.

TABLE 9

Support Ratio Differenges Between Suburban Gitizens and Officials for Ten Issues by Community Social Rank

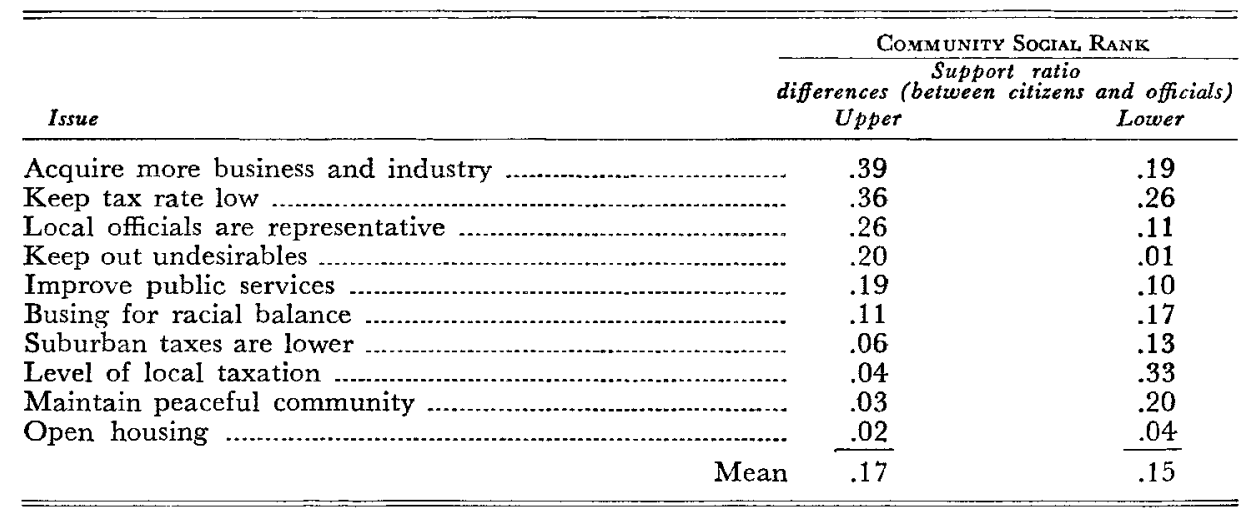

Differences in support ratio scores were less than .25 for 15 of the 20 possible paired (officials and citizens) items. Following our previous reasoning we can conclude that strong attitudinal linkages exist between suburban councilmen and their constituents on 75 percent of the selected issue areas which lends considerable support to our initial hypothesis. The greatest disparity (.39) between official and citizen outlook emerged over the value of bringing new industry and business into the upper social rank suburbs. In fact, three of the five larger support ratio discrepancies existed between upper ranked citizens and their officials and, overall, the mean support ratio differences were slightly larger (indicating more disagreement) for the two groups from the higher status suburbs (see Table 9). Several additional patterns might be identified. The most solid agreement between suburban masses and elites seems to be in those areas which are most directly concerned with maintaining the social composition of the community and with preserving social harmony. The weakest linkages pertain to taxes and the need for further economic development in the suburbs. Considerable support was found for the second hypothesis that suburbanites and their officials will tend to evaluate local government services in a similar manner with officials providing slightly higher ratings. Council members from both levels of social rank were slightly less opposed to open housing (than residents) while residents were somewhat less hostile (although still strongly opposed) to the idea of busing children to improve racial balance in schools. This finding was not completely consistent with the expectation expressed in hypothesis three. Originally it had been thought that officials might tend to overstress the importance of the protective suburban environment. The fact that elected leaders were more sympathetic than residents to open housing may be due in part to the greater immediacy of this particular issue, since a few months after the survey was taken the central city adopted an open-housing ordinance of sorts. Suburban officeholders, more than their constituents, would be likely to know of such impend- 
ing changes and perhaps realize that after the barriers fall in the central city, similar pressure might be forthcoming for action in the suburbs. On the tax issues, local officials from both types of suburb were less worried about high tax rates than were residents, which supports the fourth hypothesis.

\section{Conclusion}

The research on local representation from the Bay area has suggested that the electoral process is not an effective means for holding municipal officials accountable to those they represent. These studies offered no findings, however, that dealt with the question of whether city council members who act on the basis of their own definitions of the community interest were adhering to the policy desires of their constituents. Considerable evidence about the nature of social and political life in small communities might lead one to expect considerable attitudinal agreement between urban leaders and the general populace on basic issues of public policy. In fact, the belief-sharing political linkage model is largely based on this assumption. The research reported here that indicates rather close policy congruence between suburban officials and citizens seems to conform well to such a belief-sharing linkage model. In some settings, at least, the fear of voter retaliation may not be essential to produce harmony on issues of public policy between the elected and the electors.

While the nature of small community life may tend to produce fairly widespread sharing of certain basic values, perceptions of urban issues by local leaders will never be quite the same as for those they represent. As Eulau has observed, "The very fact of their having been elected or selected - having been 'elevated" through some mechanism of choice from one position into another-makes the 'chosen' fundamentally different from the choosers." ${ }^{36}$ Thus the viewpoint of those in leadership roles will always be affected by the special position of authority they occupy. This would seem to hold irrespective of the method for choosing leaders and without regard to whether local officials are politically ambitious. This is not to suggest, however, that responsiveness between local political elites and the masses is absent. Instead, perhaps the forms of accountability may be subtle and diverse, extending beyond the single device of elections.

How do these findings which suggest rather close attitudinal linkages between suburban citizens and officials affect notions of electoral accountability? At fundamental issue is the nature of representation itself. If our concern is not really with style, approach, or particular electoral arrangements, but with the extent to which public officials act in the interest of those they represent, then it is performance that counts. The real question is, do elected authorities adhere rather consistently to the policy demands of the larger public? What this means for the widespread assumption concerning the role of elections as the paramount vehicle for assuring representative behavior is another matter. Perhaps a belief-sharing model of political linkage is a more accurate way of conceptualizing the nature of citizen-authority relationships in certain political settings, particularly in small, middle-class suburbs.

\footnotetext{
${ }^{3}$ Heinz Eulau, "Changing Views of Representation," in Ithiel de Sola Pool, ed., Contemporary Political Science (New York: McGraw-Hill, 1967), p. 80.
} 